\title{
THE EFFECT OF SCOPE OF ANALYZED DATA ON THE VALUE OF THE HERITABILITY COEFFICIENT OF LITTER SIZE TRAITS IN PIGS
}

\author{
D. Radojković ${ }^{1}$, M. Petrović ${ }^{1}$, M. Mijatović ${ }^{1}$, Č. Radović ${ }^{2}$, M. Popovac ${ }^{1}$ \\ ${ }^{1}$ University of Belgrade, Faculty of Agriculture, Institute of Zootechnics, Nemanjina 6, 11080 \\ Belgrade-Zemun, Republic of Serbia \\ ${ }^{2}$ Institute for Animal Husbandry, Autoput 16, P. Bpx 23, 11080 Belgrade-Zemun, Republic of Serbia \\ Corresponding author: radodrag@agrif.bg.ac.rs \\ Original scientific paper
}

Abstract: Low heritability of pig litter size traits at birth (number of live born piglets - LBP and total born piglets - TBP) and weaning (number of reared piglets - RP) is one of the major problems in their genetic improvement. The effect of selection is directly proportional to trait heritability and inversely proportional to the duration of generation interval. Objective of this study was to establish presence of difference in regard to heritability coefficient values of observed traits, as well as their accuracy depending on the size of data used in the analysis. Heritability coefficients in this study were calculated based on fertility results obtained for Swedish Landrace sows on three pig farms (farms 1, 2 and 3) in the Republic of Serbia. Observed traits - LBP, TBP and RP on farms 1, 2 and 3 were analyzed in the first (2422, 1677 and 2015 litters), in the first two (4190, 2897 and 3377 litters), in the first three (5576, 3809 and 4425 litters) and all available parities (9538, 6340 and 7750 litters) by applying the adequate mixed model of the Least square method. Heritability of LBP calculated based on fertility realized in the first partus ranged from 5.6 to $16.4 \%$, TBP ranged from 7.0 to $16.8 \%$ and RP ranged from 3.4 to $7.7 \%$. Introduction into the analysis of the results pertaining to the second, third and subsequent parities lead mainly to detection of lower values of heritability coefficients for observed traits.

Key words: pigs, litter size traits, heritability coefficient

\section{Introduction}

One of the main goals of selection of any species of domestic animals is to obtain the highest possible effect of the selection. In this sense, it is of special importance to achieve the highest possible accuracy of evaluation of breeding value of animals considering it's direct influence on realized results of selection. 
Total breeding value of an animal is determined by great number of quantitative traits. Selection index is one of linear methods based on simultaneous selection on more traits. Breeding value of an animal is expressed cumulatively in selection index which is in maximum correlation with aggregate genotype.

Criteria for choice of selection index that will be applied for evaluation of breeding value of animals is correlation between index and aggregate genotype $\left(r_{I H}\right)$, as parameter which reflects accuracy of selection when certain method is used. Value of this parameter in research presented by Irvin (1975) varied from $r_{I H}$ $=0.550$ to $r_{I H}=0.690$ depending on the traits that were included in the index for evaluation of sow breeding value based on fertility traits.

Gajic et al. (1979) presented that breeding value of sows for fertility traits can most accurately be evaluated is the selection index is constructed based on number of live born piglets, mass of litter on the second day subsequent to farrowing, number of reared piglets and mass of litter on $28^{\text {th }}$ day. It was established that value of correlation coefficient between index and aggregate genotype was higher $\left(r_{I H}=0.610\right.$ in relation to $\left.r_{I H}=0.470\right)$ when parameters necessary for construction of index are calculated based on fertility results realized in first three farrowings and not only based on the first one.

Similar conclusions were made also by Knap (1986). He stated that accuracy of selection index is increased from $r_{I H}=0.180$ to $r_{I H}=0.460$ if parameters are calculated based on realized fertility in first four farrowings in relation to situation when parameters are calculated based on fertility of primiparous sows.

Accuracy of selection index was $r_{I H}=0.380$ in the research presented by Dufek and Buchta (1987), whereas, considerably higher accuracy of selection index for fertility traits were established by Korotkov (1987). Selection index constructed based on litter size at birth and weaning, as well as evaluated milk yield of sows was connected to aggregate genotype in the value of $r_{I H}=0.590$ as stated by authors.

Accuracy of constructed indices for evaluation of breeding value of female breeding animals based on realized fertility can vary based on traits included in aggregate genotype and scope of analyzed data used for calculation of necessary parameters essential for their construction, as presented by Radojković et al. (2006). Correlation coefficients in this research varied in the interval from 0.346 to 0.472 when they were calculated based on parameters determined on the basis of analysis of the fertility in primiparous sows, from $r_{I H}=0.410$ to $r_{I H}=0.502$ when analysis included also results of first two farrowings, i.e. 0.327 to 0.479 when fertility in first three farrowings was analyzed.

Objective of this paper was to establish to what extent the accuracy of constructed selection indices will change depending on the scope of analyzed data on fertility based on which the parameters necessary for construction of selection indices were established. 


\section{Materials and Methods}

For analysis of observed parameters in this study, fertility results of Swedish Landrace sows from three pig farms (farms 1,2 and 3) in the Republic of Serbia, were used. Litter size traits at birth (number of live born piglets - LBP, and total born piglets - TBP) and at weaning (number of reared piglets - RP) on farms 1,2 and 3 were analyzed based on fertility results of sows realized in the first (2422, 1677 and 2015 litters), in the first two (4190, 2897 and 3377 litters), in the first three (5576, 3809 and 4425 litters) and all available parities $(9538,6340$ and 7750 litters), according to the stated order of farms.

Mixed model of the Least Square Method was applied (LSMLMW and MIXMDL, PC-2 VERSION - Harvey, 1990) as a starting point in determination of the genetic variability of litter size traits at birth and weaning (LBP, TBP and RP), was the following:

$$
y_{i j k l m n}=\mu+P_{i}+G_{j}+S_{k}+G L_{l}+b_{l}\left(x_{i j k l m n}-\bar{x}\right)+b_{2}\left(x_{i j k l m n}-\bar{x}\right)^{2}+o_{i j k l m n}+e_{i j k l m n}
$$

where $y_{i j k l m n}$ is expression of observed trait, $P_{i}, G_{j}, S_{k}, G L_{l}$ are fixed effects of the parity, year of parity, season of parity and litter genotype, respectively. The age at farrowing was modelled as quadratic regression $\left(x_{i j k l m n}\right) . o_{i j k l m n}$ is random effect of sire (genetic variance component) and $e_{i j k l m n}$ is residual.

When the variability and correlation between fertility traits were determined in the first parity, the effect of the parity was excluded from the model.

In order to enable calculating of the heritability coefficients for litter size traits at birth (LBP and TBP) and at weaning (RP) by applying the same model, it was necessary to correct the RP for number of reared piglets in the litter in the way presented by Radojković (2001). Reason for this is the procedure of crossfostering of sows which was implemented on all three farms.

For calculation of the assessment of the heritability coefficients for fertility traits, the method of intra-class correlation between half-siblings (half - sisters) by sire was applied.

\section{Results and Discussion}

The values of the heritability coefficients and errors established based on different data size used in analysis are presented in Table 1. 
Table 1. Heritability coefficient scores $\left(\hat{h}^{2} \pm s e_{\left(\hat{h}^{2}\right)}\right)$ for litter size depending on the size of analyzed data according to farms

\begin{tabular}{|l|c|c|c|c|c|}
\hline \multirow{2}{*}{ Trait } & \multirow{2}{*}{ Farm } & \multicolumn{4}{|c|}{$\hat{h}^{2} \pm s e_{\left(\hat{h}^{2}\right)}$} \\
\cline { 3 - 6 } & & $\mathrm{I}^{*}$ & $\mathrm{I}+\mathrm{II}$ & $\mathrm{I}+\mathrm{II}+\mathrm{III}$ & all parities \\
\cline { 3 - 6 } & 1 & $0.133 \pm 0.041$ & $0.110 \pm 0.029$ & $0.089 \pm 0.022$ & $0.067 \pm 0.015$ \\
$\mathrm{LBP}^{* *}$ & 2 & $0.056 \pm 0.021$ & $0.056 \pm 0.026$ & $0.074 \pm 0.025$ & $0.071 \pm 0.019$ \\
& 3 & $0.164 \pm 0.049$ & $0.098 \pm 0.030$ & $0.100 \pm 0.027$ & $0.115 \pm 0.025$ \\
\hline \multirow{2}{*}{ TBP } & 1 & $0.168 \pm 0.045$ & $0.154 \pm 0.034$ & $0.116 \pm 0.026$ & $0.086 \pm 0.018$ \\
& 2 & $0.070 \pm 0.047$ & $0.077 \pm 0.029$ & $0.095 \pm 0.028$ & $0.081 \pm 0.021$ \\
& 3 & $0.167 \pm 0.050$ & $0.099 \pm 0.030$ & $0.099 \pm 0.027$ & $0.117 \pm 0.025$ \\
\hline \multirow{2}{*}{ RP } & 1 & $0.034 \pm 0.028$ & $0.051 \pm 0.020$ & $0.043 \pm 0.016$ & $0.037 \pm 0.011$ \\
& 2 & $0.077 \pm 0.038$ & $0.045 \pm 0.025$ & $0.027 \pm 0.018$ & $0.019 \pm 0.011$ \\
& 3 & $0.052 \pm 0.033$ & $0.051 \pm 0.023$ & $0.048 \pm 0.019$ & $0.030 \pm 0.011$ \\
\hline
\end{tabular}

* size of analyzed data: I - first partus; I+II - first two parities; I+II+III - first three parities

${ }^{* *}$ LBP - number of live born piglets; TBP - number of total born piglets; RP - number of reared piglets

The presented data show that the heritability of LBP calculated based on fertility realized in the first partus/farrowing ranged from 5.6 to $16.4 \%$. These values, with the exception of value recorded for farm $2\left(\hat{h}^{2}=0.056\right)$, are in concordance with the results obtained by Logar (2000), Cechova and Tvrdon (2002), Radojković et al. (2005), Holm et al. (2005) and Luković (2006). Value obtained on farm 2 is in concordance with values presented by Petrovic et al. (1998), Kim (2001) and Vuković (2003). Higher heritability coefficient value for LBP compared to result obtained in this research was reported by Peškovičova et al. (2002).

Introduction into analysis of the fertility results from the second, third and subsequent parities/ lead to determination of lower values of heritability coefficients for observed trait. One of the reasons could be the fact that in our production conditions, due to numerous factors, significant number of sows is culled from the breeding after the first partus/farrowing, which leads to decrease of the genetic variability between animals, resulting in determination of lower values of heritability coefficients. In support of this is also the fact that the values of heritability coefficients established based on fertility results realized in the first two parities $\left(\hat{h}^{2}=0.056-0.110\right)$, first three parities $\left(\hat{h}^{2}=0.074-0.100\right)$ and total parities $\left(\hat{h}^{2}=0.067-0.115\right)$ on different farms, ranged within considerably narrower interval, which indicated that previously described procedure was typical 
for all analyzed farms. Contrary results in regard to the effect of the size of analyzed data on values of heritability coefficients for litter size traits were obtained by Radojković et al. (2005).

Heritability coefficients for TBP determined based on fertility results realized in the first partus/farrowing ranged from 7.0 to $16.8 \%$. Considering the presence of total correlation between TBP and LBP, values of observed parameter in this scope were expected and in concordance with results reported for the same parameter by Petrović et al. (1998), Logar (2000), Kim (2001), Čechova and Tvrdon (2002), Vuković (2003), Serenius et al. (2004) and Radojković et al. (2005).

In regard to the effect of the increase of the size of analyzed data on the value of heritability coefficient for TBP, almost identical conclusions can be made like for LBP.

Heritability of RP was low and ranged from 3.4 to $7.7 \%$ when calculated based on results obtained in the first partus/farrowing. These results were similar and close to values presented by Kim (2001), Vuković (2003), Serenius et al. (2004) and Radojković et al. (2005). Higher values of heritability coefficients for RP are presented by Petrović et al. (1998) and Čechova and Tvrdon (2002).

With the increase of the size of data used in the analysis the value of observed parameter decreased on farms 2 and 3, whereas in case of farm 1 it increased insignificantly or remained at the same level. Obtained results in this sense differ from results presented by Radojković et al. (2005).

\section{Conclusion}

Coefficients of heritability of litter size traits at birth (LBP and TBP) and at weaning (RP) established in this study were low and ranged within the limits already presented in the literature. The highest value in observed parameters was established based on the analysis of the fertility results realized in the first partus/farrowing. Introduction into analysis of fertility results realized in subsequent parities did not lead to determination of higher values of heritability coefficients. This indicates the possibility and justification of the assessment of the breeding value of pigs based on the fertility results realized in the first partus/farrowing. This approach could result in better selection effects through shortening of the generation interval.

\section{Acknowledgment}

Study was financed by the Ministry of Education and Science of the Republic of Serbia, Project TR 31081 


\title{
Uticaj obima analiziranih podataka na vrednost koeficijenata heritabiliteta osobina veličine legla svinja
}

\author{
D. Radojković, M. Petrović, M. Mijatović, Č. Radović, M. Popovac
}

\section{Rezime}

U ovom radu rezultati istraživanja su pokazali da su koeficijenti heritabiliteta BŽP izračunati na osnovu plodnosti ostvarene u prvom prašenju bili u intervalu od 5,6 do $16,4 \%$, BUP u intervalu od 7,0 do $16,8 \%$ i BOP u intervalu od 3,4 do $7,7 \%$.

Uvođenje u analizu rezultata plodnosti drugog, trećeg i svih ostalih prašenja dovelo je uglavnom do utvrđivanja nižih vrednosti koeficijenata heritabiliteta posmatranih osobina.

\section{References}

ČECHOVA M., TVRDON Z. (2002): An influence of different growth ability of Czech Larg White gilts and Landrace gilts on their reproductive performance. Czech J. Anim. Sci., 47, 8, 319-327.

HARVEY W.R. (1990): User's guide for LSMLMW and MIXMDL, PC-2 Version.

HOLM B., BAKKEN M., VANGEN O., REKAYA R. (2005): Genetic analysis of age at first service, return rate, litter size, and weaning-to-first service interval of gilts and sows. Journal of Animal Science, 83, 41-48.

KIM H.J. (2001): Genetic parameters for productive and reproductive traits of sows in multiplier farms. Doctoral Dissertation. Gottingen, Faculty of Agricultural Sciences, Georg-August-University of Gottingen, $68 \mathrm{p}$.

LOGAR B. (2000): Plemenska vrednost za velikost gnezda pri prašičih v populaciji $\mathrm{z}$ več genetskimi skupinami (Breeding value for litter size in pigs in population with different genetic groups). Master's thesis.

LUKOVIĆ Z. (2006): Covariance funcions for litter size in pigs using a random regression model. Doctoral Dissertation. Ljubljana, University of Ljubljana, Biotechnical Faculty, Zootechnical Department, 93 p.

PETROVIĆ M., TEODOROVIĆ M., RADOJKOVIĆ D., KOSOVAC O. (1998): Determinacija faktora koji utiču na variranje reproduktivnih osobina krmača. Savremena poljoprivreda, 47, 5-6, 121-126.

PETROVIĆ M., VUKOVIĆ V., RADOJKOVIĆ D., BELIČOVSKI S. (1998b): Estimation of breeding value of boars based on fertility of their daughters. Macedonian Agricultural Review, 45, 1-2, 91-94. 
PEŠKOVIČOVA D., WOLF J., GROENEVELD E., WOLFOVA M. (2002): Simultaneous estimation of the covariance structure of traits from field test, station test and litter recording in pigs. Livestock Production Science, 77, 155-165.

RADOJKOVIĆ D., PETROVIĆ M., MIJATOVIĆ M. (2005): Estimation of genetic variability of fertility traits of pigs. 8th International Symposium "Modern Trends in Livestock Production", Biotechnology in Animal Husbandry, 21, 5-6, Book 2, 93-97.

RADOJKOVIĆ D. (2001): Ocena priplodne vrednosti krmača i efekti direktne i indirektne selekcije. Magistarska teza, Zemun - Beograd, Poljoprivredni fakultet Univerziteta u Beogradu, 152 str.

SERENIUS T, SEVON-AIMONEN M. -L., KAUSE A., MANTYSAARI E. A., MAKI-TANILA A (2004): Selection potencial of different prolificacy traits in the Finish Landrace and Large White populations. Acta Agric. Scan., Sect. A, Animal Sci., 54, 36-43.

VUKOVIĆ V. (2003): Estimation of genetic parameters for most important reproductive and productive traits of pigs. Doctoral Dissertation. Skopje, University " St. Cyril and Methodius " Faculty of Agriculture, 115 p. 